Vol. 14 (2005): 98-111.

\title{
Measured and simulated effects of sophisticated drainage techniques on groundwater level and runoff hydrochemistry in areas of boreal acid sulphate soils
}

\author{
Ilona Bärlund, Sirkka Tattari
}

Finnish Environment Institute, PO Box 140, FI-00251 Helsinki, Finland, e-mail: ilona.barlund@ymparisto.fi

Markku Yli-Halla

MTT Agrifood Research Finland, FI-31600 Jokioinen, Finland

Mats Åström

Department of Biology and Environmental Science, Kalmar University, SE-39182 Kalmar, Sweden

To abate the environmental problems caused by the severe acidity and high metal concentrations in rivers draining acid sulphate (AS) soils of Western Finland, control drainage (CD) and lime filter drainage (LFD), and their combination, were investigated. The effectiveness of these best management practices (BMP's) on drainage water quality was studied on plot scale in two locations. In Ilmajoki, where the sulphidic materials are more than $2 \mathrm{~m}$ below the soil surface, CD efficiently reduced the concentrations of sulphate, aluminium, manganese and iron concentrations and to some extent also increased the $\mathrm{pH}$ of the drainage waters. LFD, in contrast, effectively reduced the drainage water acidity and raised the $\mathrm{pH}$ level. Decrease of the groundwater level owing to strong evapotranspiration in summer could, however, not be properly prevented by CD. In Mustasaari where sulphidic materials were as shallow as $1 \mathrm{~m}$ below soil surface, the positive effects of LFD recognised in Ilmajoki were hardly seen. This shows, that the tested BMP's work properly, and can thus be recommended, for intensively artificially drained AS soils like in Ilmajoki where most of the acidity has already been transported to watercourses. LFD can, however, not be recommended for as yet poorly leached and thus particularly problematic AS soils like in Mustasaari. This is, of course, a drawback of the tested BMP, as it is not effective for the soils which would need it most. The field data were tentatively utilised to test the performance of the HAPSU (Ionic Flow Model for Acid Sulphate Soils) simulation model developed to estimate the loads of harmful substances from AS soils.

Key words: acid sulphate soils, control drainage, lime filter drainage, leaching, acidity, sulphate, aluminium, manganese, iron 
Vol. 14 (2005):98-111.

\section{Introduction}

Loads of acidity and several metals from agricultural land on AS soils to water courses on the western coast of Finland (Weppling 1993, Åström and Åström 1997, Edén et al. 1999) have been documented to result in adverse impacts on aquatic life (Teppo et al. 1999). The AS soils of the region are not rich in total concentration of metals but metals are extensively mobilised in the acidic environment created by oxidation of sulphides in non-calcareous soils (Sohlenius and Öborn 2004). From the agricultural point of view, many fields in the main AS soil area of Finland need more efficient drainage. Improved drainage of AS soils is likely to induce further oxidation of sulphides and, consequently, increased acidity and elevated concentrations of metals in drainage waters.

To combat the loads of acidity and metals, the lime filter drainage (LFD) method, in which 5-7\% of $\mathrm{CaO}$ is mixed with trench backfill in connection with subsurface drainage, was introduced by Palko (1994). With this technique it is possible to collect the acid surface and infiltration waters and neutralise them effectively. The expected duration of full scale LFD implementations on AS soils can be calculated from laboratory results (Weppling 1997). A normal subsurface drainage regime will, with a $10 \%$ LFD filling, give a theoretical durability of about 10 years (calculated with an annual $300 \mathrm{~mm} \mathrm{ha}^{-1}$ runoff value). These calculations will, however, only provide theoretical approximations, since they assume that $100 \%$ of the runoff will pass through the LFD material and the subsurface drains. The results obtained from Laitila in south-western Finland indicated that during the first year after commencement, an increase of ca. $1.5 \mathrm{pH}$ units was achieved when compared to conventional drainage. Triipponen (1997) reported later on that the effectiveness of LFD was decreased after the first year. After a 3year observation period the average $\mathrm{pH}$ of LFD and conventional drainage waters differed only by 0.1 $\mathrm{pH}$ units. This short period of effective neutralisation is the main critical point raised against widespread installation of LFD systems.

The purpose of control drainage (CD) is to stabilise the water management of fields and to re- duce need for irrigation and reduce runoff from fields. The basic principle of CD is to keep the groundwater level as high as possible to enable cultivation. Weir structures are used to maintain a high groundwater table during dry periods in summer when oxidation of sulphides in AS soils mostly occurs. Successful use of $C D$ requires that the slope of the field is small $(<2 \%)$ and that hydraulic conductivity is high ( $>$ about $0.5 \mathrm{~m} \mathrm{~d}^{-1}$ ) in the oxidised part of the soil profile and low deeper in the soil to prevent deep seepage. The functioning of $\mathrm{CD}$ and the factors affecting N-leaching at a field scale has been studied e.g. in Sweden by Wesström et al. (2001) and in Finland by Paasonen-Kivekäs and Karvonen (1998). In the Swedish case on loamy sand $\mathrm{CD}$ efficiently reduced nitrate leaching. The measurements in Finland showed that CD works quite satisfactorily in clayey silt soils, which contain "permanent" macropores. Near the vicinity of the control well, the groundwater level reacted almost immediately to the changes in the weir level. However, in most cases, the effect was only local, covering a small area around the well.

The main aim of this study was to investigate the functioning of LFD, CD and the combined method of LFD and CD on boreal AS soils using field data. Additional aims were to describe the variable aquatic impacts of the drainage techniques in two contrasting areas and to evaluate the HAPSU model (Ionic Flow Model for Acid Sulphate Soils, in Finnish HAPpamien SUlfaattimaiden ionivirtausmalli) (Hutka et al. 1996) performance. The study extends earlier results on soil profile characteristics (Joukainen and Yli-Halla 2003) reported from the field sites that were utilised in this study. The raw data on which this study is based is earlier presented by Bärlund et al. (2004).

\section{Material and methods}

\section{Experimental set-up}

The Ilmajoki $\left(62.72^{\circ} \mathrm{N}, 22.53^{\circ} \mathrm{E}\right)$ field on a Dystric Gleysol (FAO 1988) or a Sulfic Cryaquept (Soil 
Bärlund, I. et al. Effects of drainage techniques on groundwater level and runoff hydrochemistry

Survey Staff 1999), is situated $47 \mathrm{~m}$ above the current sea level and it is within the catchment area of river Kyrönjoki (Fig. 1). It contains sulphidic materials mostly below $200 \mathrm{~cm}$. The field was subsurface-drained in the 1930s and it has been drained with open ditches at least for 100 more years. Old tile pipes were replaced with plastic pipes in 1996. The study area consists of four plots, with an area of ca. 2 ha each. They are located on a flat field, with a slope of $0.02 \%$. In Joukainen and Yli-Halla (2003) it was measured that hydraulic conductivity at depths of $0.4-0.5 \mathrm{~m}$ and $1.0-1.1 \mathrm{~m}$ was relatively high but that there was practically no infiltration in the reduced horizons at the depths of 1.6-1.7 $\mathrm{m}$ and 1.9-2.0 m. Three different BMP's (best management practices) are applied in the field, namely, control drainage, lime filter drainage and the combination of control and lime filter drainage (LFD + CD). The reference plot has conventional subsurface drainage (REF). Drainage intensity of the fields with CD was controlled in two of the plots with weir structures in the wells. The weir level was set to $0.5 \mathrm{~m}$ below soil surface instead of the drain depth at $1.2 \mathrm{~m}$. One groundwater monitoring pipe was established in the middle of each plot extending to the depth of $3 \mathrm{~m}$. There was no backfilling of water of the $\mathrm{CD}$ systems. Thus the groundwater level was subjected to lowering by evapotranspiration. Due to very low hydraulic conductivities measured in the reduced subsoil and due to the large size of the plot neither deep nor lateral seepage was assumed.

The Mustasaari $\left(63.05^{\circ} \mathrm{N}, 21.71^{\circ} \mathrm{E}\right)$ field on Thionic Gleysol (FAO 1988) or a Sulfic Cryaquept (Soil Survey Staff 1999), is in a polder at the current sea level. It contains sulphidic materials at a depth of $110 \mathrm{~cm}$. Infiltration in the clay soil between the depth of 0.3 and $0.8 \mathrm{~m}$ varied from 16 to $96 \mathrm{~cm}$ per day in the measurements performed by Joukainen and Yli-Halla (2003). The polder was constructed at the end of 1950s and the area was subsurface-drained in 1969. The field consists of five large $(24 \mathrm{~m} \times 30 \mathrm{~m})$ plots where $\mathrm{CD}$, LFD, LFD + CD and REF were applied. The fifth large plot had intensive surface liming but it is not part of the study presented here. The old subsurface drainage pipes at $1.1 \mathrm{~m}$ depth were blocked and the

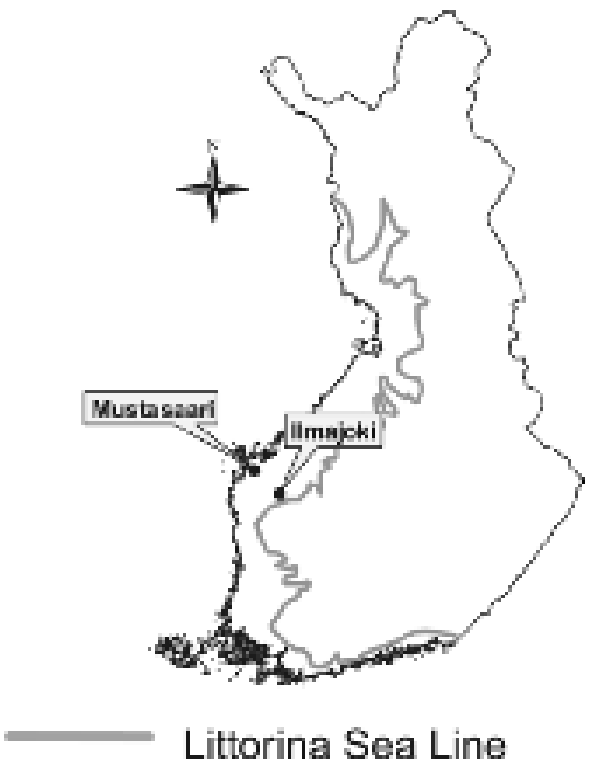

Fig. 1. Location of the research fields.

new ones were installed at the depth of $1.0 \mathrm{~m}$ in 1998. One groundwater monitoring pipe was established in the middle of all the plots extending to the depth of $2.5 \mathrm{~m}$. In Mustasaari, the field was divided into plots, which were separated from each other by the installation of plastic sheets to a depth of $1.3 \mathrm{~m}$, as an attempt to prevent lateral seepage (Joukainen and Yli-Halla 2003).

In both fields, samples of drainage water were taken 1-2 times per week after the intensive snowmelt period in spring and during the autumn period. The total number of sampling times was 41-53 for the different plots in Ilmajoki in the five-year period 1998-2002, and 43-48 for the different plots in Mustasaari in the three-year period 19992001. Before sampling the wells were emptied unless the weir was used to maintain a higher groundwater table. In that case, the samples were taken from the well. The samples were principally analysed for $\mathrm{pH}$, acidity, sulphate sulphur $\left(\mathrm{SO}_{4}-\mathrm{S}\right)$, total and dissolved iron $(\mathrm{Fe})$, total manganese $(\mathrm{Mn})$ as well as total and dissolved aluminium (Al). The $\mathrm{pH}$ was measured using a potentiometer. Acidity 
Vol. 14 (2005):98-111.

was also measured with a potentiometer (titration to $\mathrm{pH}$ 8.3). $\mathrm{SO}_{4}-\mathrm{S}$ was analysed using liquid chromatography. Total $\mathrm{Fe}$ was analysed by first oxidising with peroxide sulphate and then reducing with hydroxyl ammonium chloride. The absorbency was measured at wave length $593 \mathrm{~nm}$. Total Al was measured using the pyrocatechol violet spectrophotometry determination method at a wavelength of $580 \mathrm{~nm}$. In order to measure dissolved $\mathrm{Fe}$ and $\mathrm{Al}$ the samples were filtrated $(0.45 \mu \mathrm{m}$ filter $)$. Total Mn was analysed by oxidising with peroxide sulphate. The absorbency was measured at wave length $450 \mathrm{~nm}$. Groundwater level was measured weekly throughout the year. Details of the sampling strategy, analytical methods applied and the agricultural management practices are described in the final report of the HAPSU project (Bärlund et al. 2004).

In order to analyse the effect of the CD, LFD and LFD + CD methods on the various water quality variables measured, a simple statistical test was performed. A $t$-Test, paired two samples for means (Ranta et al. 1991), was chosen in which the results of the plots with CD, LFD or LFD + CD were compared with the results from the reference plot for each observation date. The test was performed over the whole observation period, i.e. 1998-2002 in Ilmajoki and 1999-2001 in Mustasaari.

\section{The HAPSU model}

The HAPSU model (Hutka et al. 1996) is an ionic flow model developed for AS soils based on the SMASS model (Simulation Model for Acid Sulphate Soils) (Bronswijk et al. 1992). It simulates $\mathrm{SO}_{4}-\mathrm{S}, \mathrm{H}^{+}, \mathrm{Fe}$ and $\mathrm{Al}$ leaching from runoff areas build up with AS soils and non-acid soils. The model calculates the passage of heat, water, oxygen and liquids in a soil column. AS soils and non-acid soils are considered separately in the model (Fig. 2). Driving data to run the model are climate data, i.e. daily precipitation and air temperature measurements and 5-day-sum of potential evaporation. The hydrological part of the model simulates snow accumulation and melting according to Vehviläinen (1992). Evapotranspiration can take place from soil, depression storage and directly from snow cover. Soil cracking is described by Bronswijk (1988) and water flow in the soil is assumed to be laminar and is calculated based on the Richards equation (1931). The soil heat flow is calculated with general heat flow equations. The chemistry part of the model includes processes such as the effect of freezing and melting on water quality, transport of oxygen, development and transport of carbon dioxide, oxidation and weathering processes and transport of
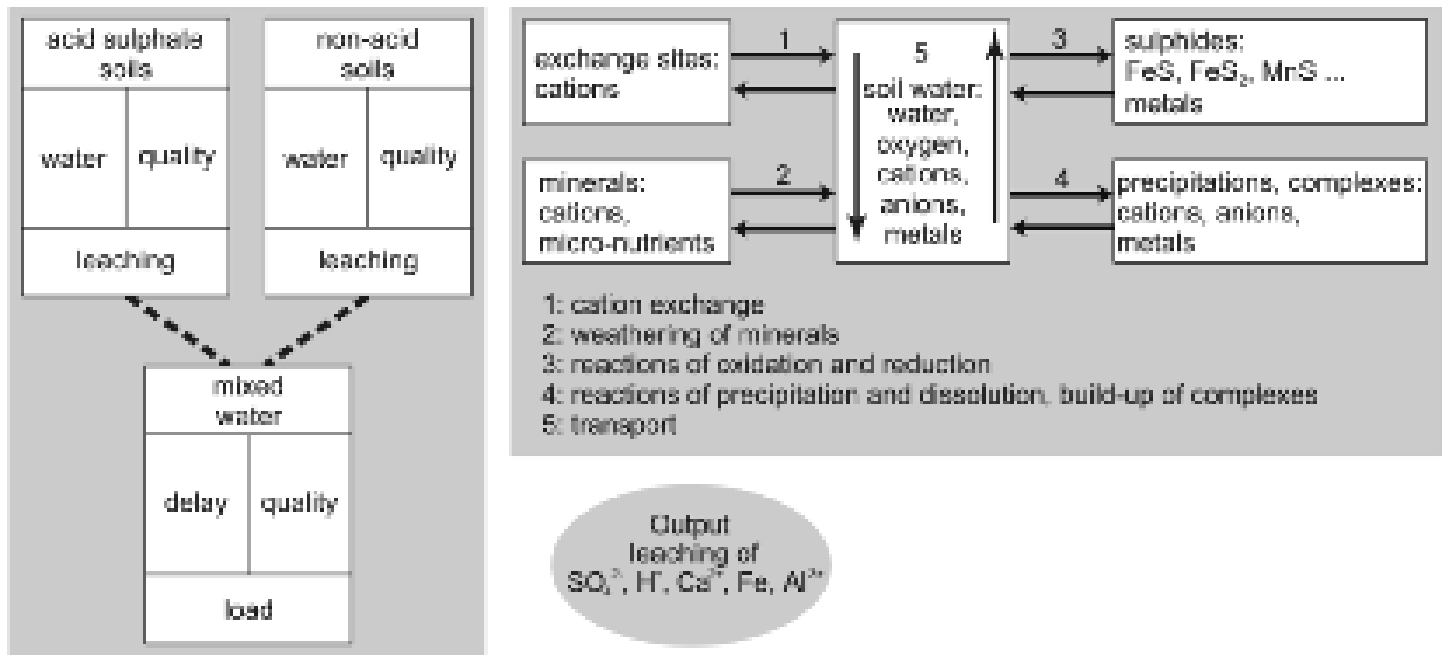

Fig. 2. The components of the HAPSU model. 
solutes. The ion exchange equilibrium is calculated separately for each soil layer. The reactions included in the model are cation exchange reactions based on de Vries et al. (1989), carbon dioxide equilibrium and $\mathrm{Al}$ and $\mathrm{Fe}$ reactions by Stumm and Morgan (1981).

For simulations in Ilmajoki, the climatic data were received from a station at the research field during the vegetative period and the nearby Ylistaro climate station during the remaining part of the year. Data needed to parameterise the model are mainly on soil properties and they were derived from field measurements in Ilmajoki, from earlier simulation work in nearby catchments and from literature. Finally, data about the depth of the groundwater table, needed to calibrate the model, was acquired from the field plots at Ilmajoki. In order to test the model on field scale, both with and without BMP's, data on $\mathrm{pH}$ and $\mathrm{SO}_{4}-\mathrm{S}$, total $\mathrm{Fe}$ and total $\mathrm{Al}$ concentrations of drainage water from the Ilmajoki field plots was used.

In the HAPSU model two routines are included to allow simulation of control drainage and lime filter drainage. In CD the depth of the groundwater table is set to a given height, e.g. $0.5 \mathrm{~m}$ below the soil surface. Additionally, the time period for which the high groundwater table is active has to be defined. For LFD the neutralising capacity of the lime cover around the drainage pipes has to be defined. For this purpose six variables are required: the share of LFD of the total field area (here 0.02, i.e. $2 \%$ ), the water conductivity of the drains $(0.1$ $\left.\mathrm{m} \mathrm{d}^{-1}\right)$, the discharge rate of LFD $\left(1 \times 10^{-5} 1 \mathrm{~s}^{-1}\right)$, the amount of lime $\left(15 \mathrm{~kg} \mathrm{~m}^{-1}\right)$, the percentage of lime solubility $(50 \%)$ and a solubility factor $(1 \times$ $\left.10^{-2} 1 \mathrm{~m}^{-1}\right)$.

The effectiveness of BMP's on drainage water quantity and quality can be studied on plot scale using hydrochemical and geochemical field data. For a study on larger scale, such as small catchments, the use of a model such as HAPSU is however needed for BMP effectiveness analysis. The results from the Ilmajoki research field were utilised to calibrate the hydrological part of the HAPSU model. The chemical part of the model is however uncalibrated in this study, since this is part of future model development.

\section{Results and discussion}

\section{Field data}

The average values of all measured variables in the reference plots with ordinary subsurface drainage are presented in Table 1 for Ilmajoki (1998-2002) and Mustasaari (1999-2001). These data show, for example, that the measured drainage water acidities (Fig. 3a) as well as total aluminium concentrations (Fig. 3b) were clearly higher in Mustasaari than in Ilmajoki. Also, in Mustasaari all determinants were considerably higher than what is found in non-AS soils affected (or only marginally AS soils-affected) streams in central Finland (Table 1). An earlier study of these sites indicated that even quite deep sulphidic layers ( $>2 \mathrm{~m}$ from soil surface) give rise to adversely acidic drainage waters in subsurface-drained AS soils. In these soils CD can, however, alleviate the problem by submerging the sulphidic layers. Instead, in soils with sulphidic materials close (about $1 \mathrm{~m}$ ) to soil surface, $C D$ is not able to keep the sulphidic materials submerged and prevent them from oxidising. Therefore the authors concluded that $\mathrm{CD}$ may practically be a more useful measure in soils with deep sulphidic layers (Joukainen and Yli-Halla 2003).

In the drainage waters from Ilmajoki, all the measured determinants occurred in lower concentrations than those from Mustasaari, where the sulphidic materials were much closer to soil surface and, thus, more vulnerable to oxidation. There was also a clear difference between Ilmajoki and Mustasaari research fields as to the effect of the BMP's applied. The results indicate (Table 2) that, with a few exceptions, in Ilmajoki the CD, LFD or LFD + CD caused statistically significant improvement of drainage water quality as compared to the reference plot. In general, the CD or CD + LFD produced a reduction in all measured concentrations for all variables whereas LFD did not affect $\mathrm{SO}_{4}-\mathrm{S}$, total Fe and total Al. The LFD, however, caused a greater increase in $\mathrm{pH}$ and decrease in acidity than the methods involving $\mathrm{CD}$. The greatest decreases were observed for the average dissolved $\mathrm{Fe}$ and $\mathrm{Al}$ 
Vol. 14 (2005):98-111.
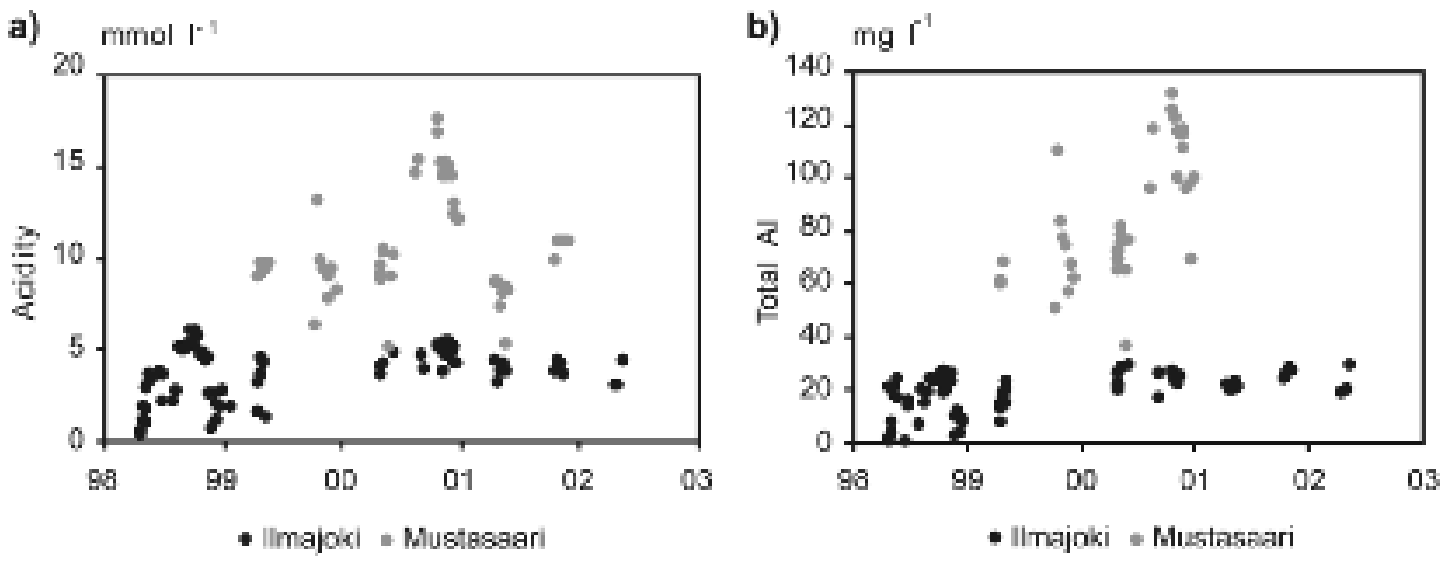

Fig. 3. Drainage water acidity (a) and total aluminium concentrations (b) from the reference fields in Ilmajoki and in Mustasaari in the years 1998-2002.

Table 1. Average measured values of drainage water variables in the reference plots over the whole observation period and their standard deviation (STD) compared with values measured in stream waters in central Finland (Lahermo et al. 1996).

\begin{tabular}{lccccc}
\hline $\begin{array}{l}\text { Drainage water } \\
\text { variables }\end{array}$ & \multicolumn{2}{c}{ Ilmajoki } & \multicolumn{2}{c}{ Mustasaari } & Streams \\
mean & STD & mean & STD & range \\
\hline $\mathrm{pH}$ & 4.3 & 0.51 & 3.7 & 0.084 & - \\
Acidity $\left[\mathrm{mmol} \mathrm{l}^{-1}\right]$ & 3.9 & 1.3 & 11 & 2.8 & - \\
$\mathrm{SO}_{4}^{2-}-\mathrm{S}\left[\mathrm{mg} \mathrm{l}^{-1}\right]$ & 441 & 140 & 2312 & 977 & $100-400$ \\
${\mathrm{Total} \mathrm{Mn}\left[\mu \mathrm{g} \mathrm{l}^{-1}\right]}_{\text {Total Fe }\left[\mu \mathrm{g} \mathrm{l}^{-1}\right]}$ & 8115 & 1749 & 16414 & 2739 & $100-200$ \\
Dissolved Fe $\left[\mu \mathrm{g} \mathrm{l}^{-1}\right]$ & 117 & 1140 & 3687 & 3700 & $1000-1400$ \\
Total Al $\left[\mu \mathrm{g} \mathrm{l}^{-1}\right]$ & 19741 & 7749 & 88070 & 25617 & $200-1000$ \\
Dissolved Al $\left[\mu \mathrm{g} \mathrm{l}^{-1}\right]$ & 20773 & 5740 & n.a. & n.a. & - \\
\hline
\end{tabular}

n.a. $=$ not analysed

for the number of observations in Ilmajoki and Mustasaari see Table 2

concentrations which were reduced to $1 / 12$ and $1 / 13$, respectively, using the combined LFD + CD method compared to the REF plot. In contrast, in Mustasaari there were few differences between the treatment methods.

Among the determined metals, the total $\mathrm{Al}$ and $\mathrm{Mn}$ concentrations drastically exceeded those commonly occurring in Finnish streams (Lahermo et al. 1996). Of these, $\mathrm{Al}$ is more harmful for aquatic life. It is noteworthy that in the drainage water from the REF plots in Ilmajoki all $\mathrm{Al}$ was in dissolved form. CD somewhat decreased the total $\mathrm{Al}$ concentration probably by retarding the oxidation of sulphides and thereby the production of acidity and a consequent mobilisation of Al. But also in the $\mathrm{CD}$ waters all $\mathrm{Al}$ was in the dissolved form. The LFD, instead, strongly lowered the concentration of dissolved Al, a phenomenon caused by the elevation in drainage water $\mathrm{pH}$. Abundant concentration of total $\mathrm{Al}$ in those waters suggest that $\mathrm{Al}$ mobilisation from the LFD plots was nearly as large as in the REF plots but the mobilised $\mathrm{Al}$ was hydrolysed and entered the drain in the form of fine precipitate. The results suggest that in the LFD + CD treatment oxidation of sulphides and thus mobilisation of $\mathrm{Al}$ is retarded and the dissolved $\mathrm{Al}$ is precipitated to a considerable extent, in concert with the elevated $\mathrm{pH}$ of the drainage wa- 
Bärlund, I. et al. Effects of drainage techniques on groundwater level and runoff hydrochemistry

Table 2. $\mathrm{pH}$, acidity, $\mathrm{SO}_{4}-\mathrm{S}$, total $\mathrm{Mn}$, total and dissolved $\mathrm{Fe}$ and $\mathrm{Al}$ concentration in water samples from the Ilmajoki and Mustasaari fields in the plots with control drainage (CD), lime filter drainage (LFD) and their combination (LFD + CD) compared to the reference plot with conventional subsurface drainage (REF).

\begin{tabular}{|c|c|c|c|c|c|c|c|c|}
\hline & \multicolumn{4}{|c|}{ Ilmajoki } & \multicolumn{4}{|c|}{ Mustasaari } \\
\hline & $\mathbf{C D}^{\mathrm{a}}$ & $\mathbf{R E F}^{\mathrm{a}}$ & $\mathbf{t}^{\mathrm{b}}$ & $\mathbf{n}^{\mathrm{c}}$ & $\mathbf{C D}^{\mathrm{a}}$ & $\mathbf{R E F}^{\mathrm{a}}$ & $\mathbf{t}^{\mathrm{b}}$ & $\mathbf{n}^{\mathrm{c}}$ \\
\hline $\mathrm{pH}$ & 4.6 & 4.3 & $6.19 * * *$ & 73 & 3.7 & 3.7 & $0.56^{\text {n.s. }}$ & 47 \\
\hline acidity $\left[\mathrm{mmol} \mathrm{l}^{-1}\right]$ & 3.4 & 3.9 & $-3.81 * * *$ & 64 & 9.7 & 11 & $-2.68^{\text {n.s. }}$ & 46 \\
\hline $\mathrm{SO}_{4}-\mathrm{S}\left[\mathrm{mg} \mathrm{l}^{-1}\right]$ & 331 & 441 & $-6.97 * * *$ & 68 & 1917 & 2312 & $-4.00 * * *$ & 31 \\
\hline $\mathrm{Mn}$, tot $\left[\mu \mathrm{g} \mathrm{l}^{-1}\right]$ & 3103 & 4115 & $-5.04 * * *$ & 63 & 15170 & 16414 & $-2.34^{\text {n.s. }}$ & 20 \\
\hline $\mathrm{Fe}$, tot $\left[\mu \mathrm{g}^{-1}\right]$ & 293 & 870 & $-4.91 * * *$ & 72 & 3753 & 3700 & $0.12^{\text {n.s. }}$ & 31 \\
\hline Fe, filt $\left[\mu \mathrm{g} \mathrm{l}^{-1}\right]$ & 45 & 117 & $-8.11 * * *$ & 32 & n.a. & n.a. & n.a. & n.a. \\
\hline $\mathrm{Al}$, tot $\left[\mu \mathrm{g}^{-1}\right]$ & 10891 & 19741 & $-8.84 * * *$ & 61 & 65201 & 88070 & $-5.05 * * *$ & 29 \\
\hline \multirow[t]{2}{*}{$\mathrm{Al}$, filt $\left[\mu \mathrm{g} \mathrm{l}^{-1}\right]$} & 11408 & 20773 & $-9.31 * * *$ & 26 & n.a. & n.a. & n.a. & n.a. \\
\hline & $\mathbf{L F D}^{\mathbf{a}}$ & $\mathbf{R E F} \mathbf{F}^{\mathbf{a}}$ & $\mathbf{t}^{\mathrm{b}}$ & $\mathbf{n}^{\mathrm{c}}$ & $\mathbf{L F D}^{\mathrm{a}}$ & $\mathbf{R E F}^{\mathrm{a}}$ & $\mathbf{t}^{\mathrm{b}}$ & $\mathbf{n}^{\mathrm{c}}$ \\
\hline $\mathrm{pH}$ & 5.9 & 4.3 & $11.2 * * *$ & 73 & 3.7 & 3.7 & $2.76^{* *}$ & 47 \\
\hline acidity $\left[\mathrm{mmol} \mathrm{l}^{-1}\right]$ & 2.1 & 3.9 & $-15.8 * * *$ & 64 & 9.8 & 11 & $-3.42 * *$ & 46 \\
\hline $\mathrm{SO}_{4}-\mathrm{S}\left[\mathrm{mg} \mathrm{l}^{-1}\right]$ & 416 & 441 & $-1.99^{\text {n.s. }}$ & 68 & 2153 & 2312 & $-1.69^{\text {n.s. }}$ & 31 \\
\hline $\mathrm{Mn}$, tot $\left[\mu \mathrm{g} \mathrm{l}^{-1}\right]$ & 3510 & 4115 & $-3.70 * * *$ & 63 & 16090 & 16414 & $-0.82^{\text {n.s. }}$ & 20 \\
\hline $\mathrm{Fe}$, tot $\left[\mu \mathrm{g} \mathrm{l}^{-1}\right]$ & 604 & 870 & $-1.83^{\text {n.s. }}$ & 72 & 3346 & 3700 & $-0.60^{\text {n.s. }}$ & 31 \\
\hline $\mathrm{Fe}$, filt $\left[\mu \mathrm{g} \mathrm{l}^{-1}\right]$ & 26 & 117 & $-19.1 * * *$ & 32 & n.a. & n.a. & n.a. & n.a. \\
\hline $\mathrm{Al}$, tot $\left[\mu \mathrm{g}^{-1}\right]$ & 15430 & 19741 & $-1.49^{\text {n.s. }}$ & 61 & 71051 & 88070 & $-4.04 * * *$ & 29 \\
\hline \multirow[t]{2}{*}{$\mathrm{Al}$, filt $\left[\mu \mathrm{g} \mathrm{l}^{-1}\right]$} & 4870 & 20773 & $-12.0 * * *$ & 26 & n.a. & n.a. & n.a. & n.a. \\
\hline & $\mathbf{L F D + C D}{ }^{\mathrm{a}}$ & $\mathbf{R E F}^{\mathrm{a}}$ & $\mathbf{t}^{\mathrm{b}}$ & $\mathbf{n}^{\mathrm{c}}$ & $\mathbf{L F D + C D ^ { \mathrm { a } }}$ & $\mathbf{R E F}^{\mathrm{a}}$ & $\mathbf{t}^{\mathrm{b}}$ & $\mathbf{n}^{\mathrm{c}}$ \\
\hline $\mathrm{pH}$ & 6.2 & 4.3 & $14.1 * * *$ & 73 & 3.6 & 3.7 & $-2.22^{\text {n.s. }}$ & 47 \\
\hline acidity $\left[\mathrm{mmol} \mathrm{l}^{-1}\right]$ & 1.9 & 3.9 & $-13.5 * * *$ & 64 & 11 & 11 & $1.58^{\text {n.s. }}$ & 46 \\
\hline $\mathrm{SO}_{4}-\mathrm{S}\left[\mathrm{mg} \mathrm{l}^{-1}\right]$ & 384 & 441 & $-4.60 * * *$ & 68 & 2348 & 2312 & $0.317^{\text {n.s. }}$ & 31 \\
\hline $\mathrm{Mn}$, tot $\left[\mu \mathrm{g} \mathrm{^{-1 }}\right]$ & 2887 & 4115 & $-6.47 * * *$ & 63 & 17663 & 16414 & $2.21^{\text {n.s. }}$ & 20 \\
\hline $\mathrm{Fe}$, tot $\left[\mu \mathrm{g}^{-1}\right]$ & 308 & 870 & $-4.68 * * *$ & 72 & 4612 & 3700 & $1.21^{\text {n.s. }}$ & 31 \\
\hline $\mathrm{Fe}$, filt $\left[\mu \mathrm{g} \mathrm{l}^{-1}\right]$ & 9.7 & 117 & $-12.8 * * *$ & 32 & n.a. & n.a. & n.a. & n.a. \\
\hline $\mathrm{Al}$, tot $\left[\mu \mathrm{g}^{-1}\right]$ & 11995 & 19741 & $-3.18^{* *}$ & 61 & 88767 & 88070 & $0.21^{\text {n.s. }}$ & 29 \\
\hline $\mathrm{Al}$, filt $\left[\mu \mathrm{g} \mathrm{l}^{-1}\right]$ & 1566 & 20773 & $-17.6 * * *$ & 26 & n.a. & n.a. & n.a. & n.a. \\
\hline
\end{tabular}

${ }^{a}$ Average for the whole measurement period; ${ }^{b}$ The test value of the t-test of paired measurements; ${ }^{c}$ Number of water sample pairs

** and ***: significant at $\mathrm{P}=0.01$ and 0.001 , respectively; n.s. not significant $(\mathrm{P}>0.02)$; n.a. not analysed

ter. The synergistic effect of LFD and CD on water quality can be further attributed to the partial water logging of the subsoil. Reduced (or less oxidised) conditions retard the transformation of divalent $\mathrm{Fe}$ to the trivalent form, which would be readily precipitated as iron hydroxide. It can be concluded that precipitation would be most abundant on the surfaces of the lime particles of the LFD. CD thus protects the lime from being blocked by iron hydroxide coating and may make the effective period of the LFD use longer.

Alasaarela (1982) observed a statistically significant correlation between river water $\mathrm{pH}$ and $\mathrm{SO}_{4}-\mathrm{S}$ concentration as well as between ditch water $\mathrm{pH}$ and total $\mathrm{Al}$ and $\mathrm{Mn}$ concentrations in areas of AS soils. In this study, a strong correlation be- tween acidity and total $\mathrm{Al}$ concentration, not only when the areas are considered separately (Fig. 4a), but also when considered as one dataset $\left(\mathrm{R}^{2}=\right.$ 0.96), was found. This indicates a continuum of the processes controlling the Al leaching. A similar correlation, to acidity, was found for $\mathrm{SO}_{4}-\mathrm{S}$ (Fig. $4 \mathrm{~b}, \mathrm{R}^{2}=0.93$ when considered as one dataset) and total Mn (Fig. 4c, $\mathrm{R}^{2}=0.93$ when considered as one dataset) but not for total Fe. These correlations reflect the following phenomena: Oxidation of sulphide produces $\mathrm{SO}_{4}-\mathrm{S}$ and acidity, and concomitantly releases $\mathrm{Fe}$ in the soils. In the acidic environment, $\mathrm{Mn}$ and $\mathrm{Al}$ are released by the weathering of aluminosilicates, and $\mathrm{Mn}$, in addition, by dissolution of Mn-bearing sulphides (Öborn 1991, Åström 1998). In the soil solution, $\mathrm{SO}_{4}-\mathrm{S}, \mathrm{Mn}$ and 
Vol. 14 (2005):98-111.

$\mathrm{Al}$ are highly soluble and consequently abundantly leached when the soils are flushed. In contrast, Fe, which is oxidised to $\mathrm{Fe}(+\mathrm{III})$, is highly immobile in the soil due to precipitation of Fe-oxyhydroxides throughout the soil column. Iron is thus not leached abundantly, which is in line with several

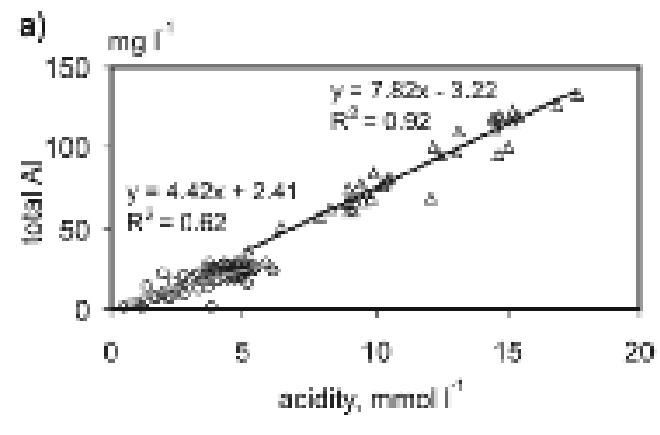

- Ilmajaki s Mustasaari - rel(I) - rel(M)

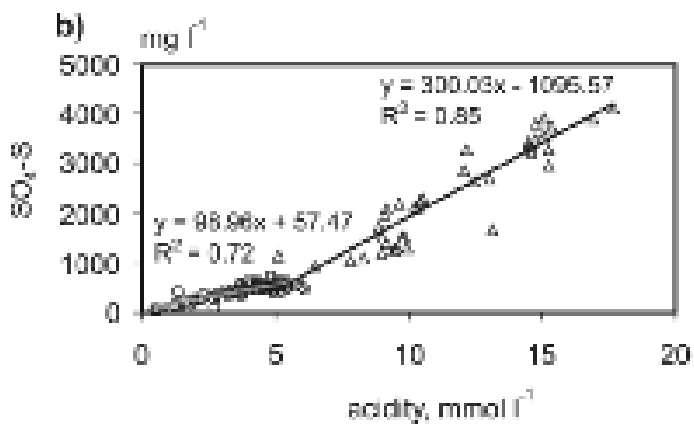

- llmajoki a Mustesaeri - rel(I) - rel(M)

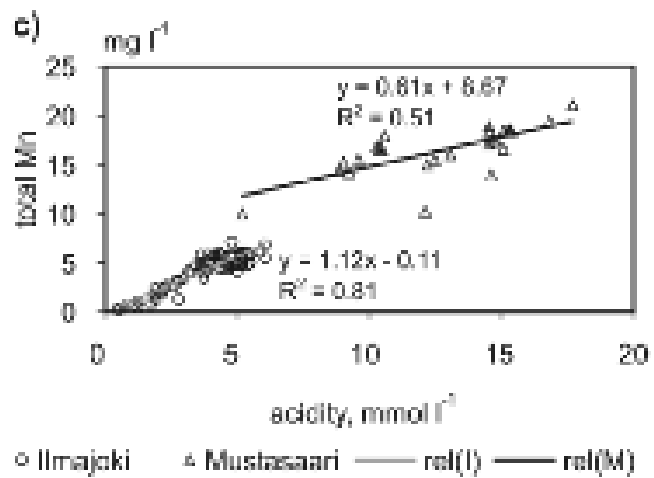

Fig. 4. Relation between drainage water acidity and (a) total aluminium, (b) sulphate sulphur and (c) total manganese concentrations for the reference fields in Ilmajoki and Mustasaari in the years 1998-2002. previous studies carried out in the boreal zone (Åström and Björklund 1995, Åström and Åström 1997, Åström and Spiro 2000), but which is in sharp contrast to AS soils e.g. in Australia which deliver an abundance of this metal (Sammut et al. 1996).

For graphical and more detailed output, the effect of the BMP's was calculated as a relative change of each characteristic (except $\mathrm{pH}$ ) from the plots where modified drainage methods were applied in regard to the result from the reference plot with ordinary subsurface drainage:

change $-\%=$

$\frac{\text { Measurement }_{\text {method }}-\text { Measurement }_{\text {reference }}}{\text { Measurement }}$ reference $* 100$

For $\mathrm{pH}$, a simple difference was calculated in $\mathrm{pH}$ units. A negative value means a decrease compared to the reference plot, a positive value an increase in regard to the reference plot. In Ilmajoki, as an example, CD, LFD and CD + LFD increased drainage water $\mathrm{pH}$ after the year 2000 (Fig. 5). The effect was the most stable for the combined method CD + LFD, where still five years after the installation of the drainage system an increase of about 2 $\mathrm{pH}$ units was observed. In Mustasaari, on the contrary, a slight increase was observed only in the first year and after that there was no difference between the methods. For total Al, a decrease in the concentration was observed for all methods in the years 1999-2002 in Ilmajoki (Fig. 6a), the greatest and most stable reduction being for the combined LFD + CD method. In Mustasaari both reductions and increases in 1999 and 2000 were observed (Fig. 6b).

The presented results have to be viewed in the light of certain restrictions. Due to missing baseline measurements on drainage water quality before implementation of the BMP's, an analysis of possible systematic differences between the plots had to be based on possible trends in soil properties. At Ilmajoki, for example, the measurements performed indicated that there was a trend of the total sulphur content in soil in the lowest measured soil layer $(2.8-3 \mathrm{~m})$ and in the thickness of the acidic layer (Bärlund et al. 2004, page 20), the $S$ 
Bärlund, I. et al. Effects of drainage techniques on groundwater level and runoff hydrochemistry

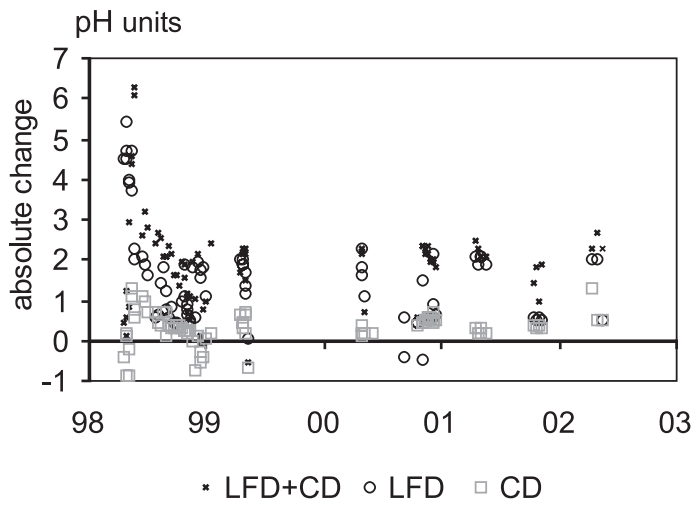

Fig. 5. Absolute change in drainage water $\mathrm{pH}$ due to methods applied when compared with the reference field: combined lime filter and control drainage (LFD + CD), lime filter drainage (LFD) and control drainage (CD) in Ilmajoki for the years 1998-2002.

content increases and the thickness of the acidic layer decreases from the most eastern plot to the most western plot. There are signs of soil profile disturbance after installing the drainage systems. In the first years of measurements in Ilmajoki, in $1998 / 99$, very low acidity values and metal concentrations were detected also in the reference plots (Fig. 3). This might result from top soil getting mixed with subsoil in the drainage trenches when refilling after the installation of the drainage pipes. Due to management problems in applying $\mathrm{CD}$ in Mustasaari, i.e. it was not always clearly recorded if the weir controlling $\mathrm{CD}$ was open or closed (surprises apparently due to vandalism), the effect of this technique cannot be evaluated with sufficient certainty. This "result" emphasises, however, how important technical understanding, motivation and alertness is in a successful application of CD.

\section{Modelling results}

When comparing the simulated results with the measured groundwater level at the Ilmajoki test field, it was noted that the general level of the groundwater can be simulated fairly well (Fig. 7, Nash-Sutcliffe index 0.18 and linear correlation coefficient $\mathrm{R}^{2} 0.47$ with 160 measurement-simulation pairs) but that certain events or time periods such as decrease in the groundwater level during the winter period 1999, probably due to soil frost conditions, could not be correctly depicted by the model. Some parameters were distinguished as being particularly influential for the groundwater depth simulation: parameters in the evapotranspiration equation, parameters affecting the lateral flow towards the drains and parameters describing the dependence between water content and matric potential. These were utilised to calibrate the hy-
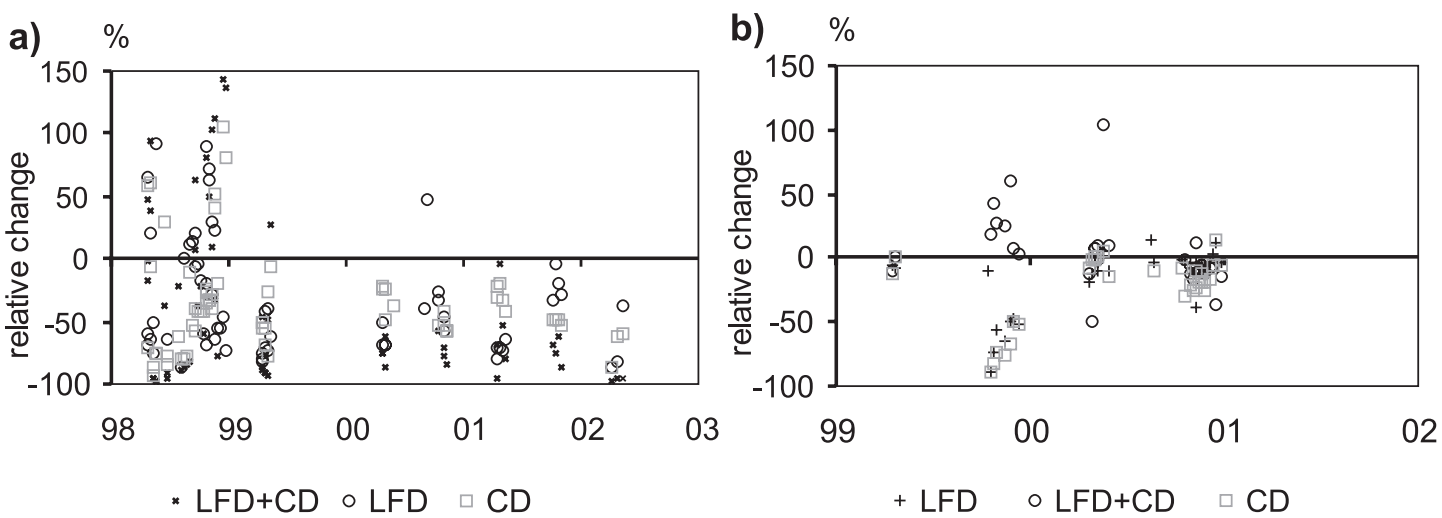

Fig. 6. Relative change in drainage water total aluminium concentration due to methods applied when compared with the reference field: combined lime filter and control drainage (LFD + CD), lime filter drainage (LFD) and control drainage (CD) in Ilmajoki (a) and Mustasaari (b) in the years 1998-2002. 
Vol. 14 (2005):98-111.

1998

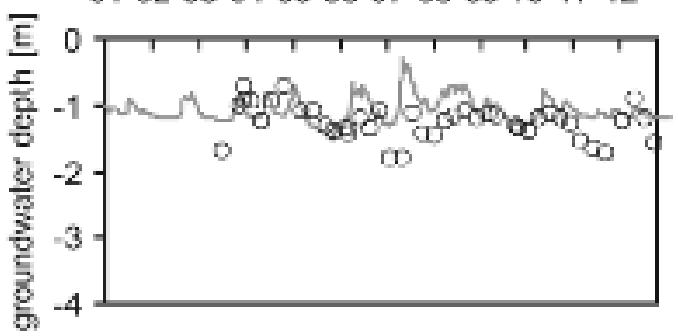

- Sirrulated $\odot$ Measured

months

$2000 \quad 010203040506070809101112$

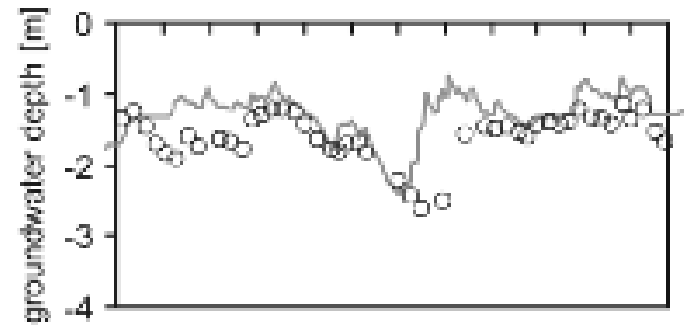

1999

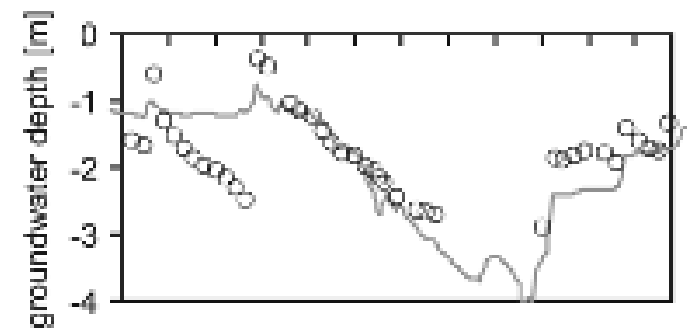

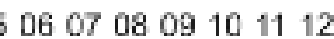

months

months

$\begin{array}{lllll}2001 \quad 0102030405 \quad 06 & 070809 & 08 & 11 & 12\end{array}$

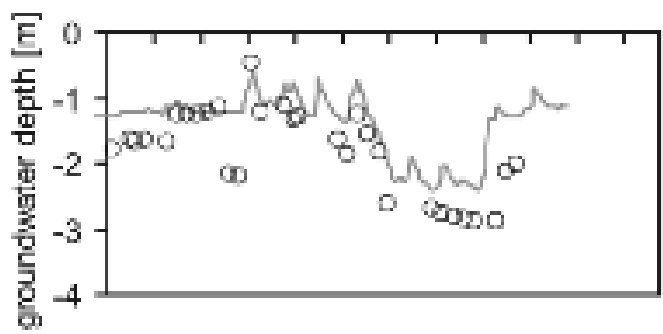

Fig. 7. Simulated (line) and measured (circles) groundwater levels for the plot with ordinary sub-surface drainage in Ilmajoki in the years $1998-2001$.

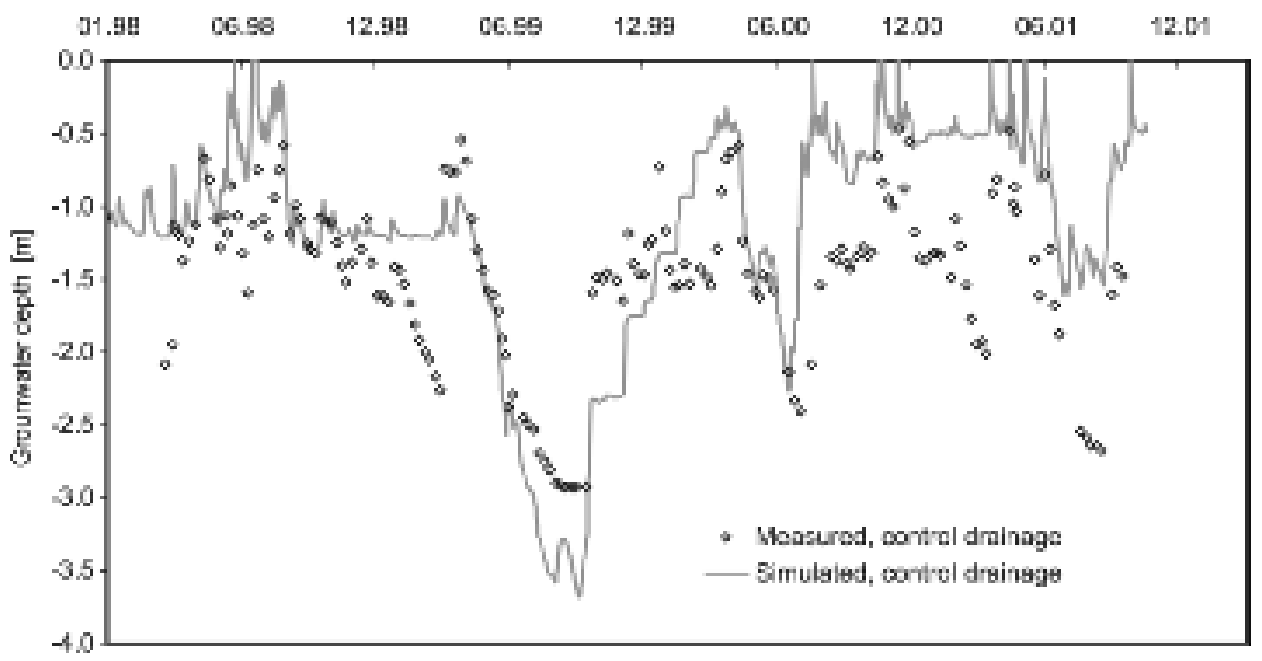

Fig. 8. Simulated (lines) and measured (circles) groundwater levels for the plot with control drainage in Ilmajoki in the years 1998-2001.

drological part of HAPSU. In general, CD increases the simulated groundwater level in relation to the reference condition but in certain periods, e.g. autumn 2000 to summer 2001, the simulated groundwater level was unrealistically high when compared with the measured level (Fig. 8). 
Bärlund, I. et al. Effects of drainage techniques on groundwater level and runoff hydrochemistry

The simulated, uncalibrated drainage water $\mathrm{pH}$ was very stable when compared to the measured values over time. For the $\mathrm{CD}$ method there was no effect in simulated $\mathrm{pH}$ (Fig. 9a). This is the method where also the measured change due to the BMP was the smallest after the first year. The baseline level of the reference plot could be relatively well simulated by the present model set-up but the BMP effect was not dynamic enough, neither for LFD (Fig. 9b) nor CD. For LFD the underestimation was several $\mathrm{pH}$ units.

In line with simulated $\mathrm{pH}$, also the simulated total $\mathrm{Al}$ concentration behaved in a constant man- ner when compared to the measurements which were much more scattered (Fig. 10). The simulated Al concentration showed additionally a decreasing trend which was not seen in the measured data series. Only $\mathrm{CD}$ decreases the simulated $\mathrm{Al}$ concentrations in drainage water (Fig. 10a), but the effect was much smaller than the measurements indicate. In contradiction to $\mathrm{pH}$, the LFD method seemed to have no effect on total $\mathrm{Al}$ (Fig. 10b). The Al concentrations in drainage waters were, for the field without BMP especially, underestimated by the current uncalibrated model set-up. a)

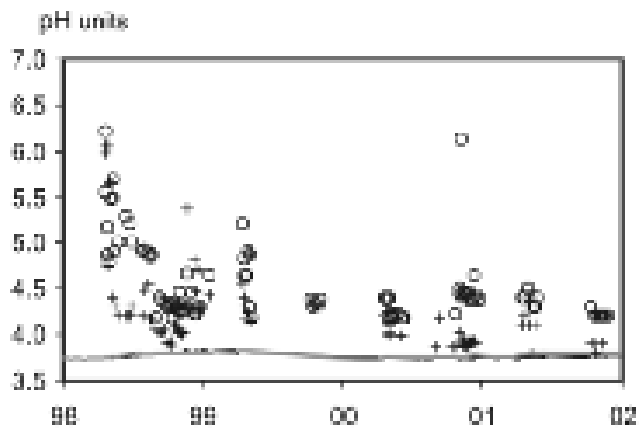

$-\operatorname{sim}$, REF + mess,REF — $\operatorname{sim}, \mathrm{CO}$ o mass, CD b)

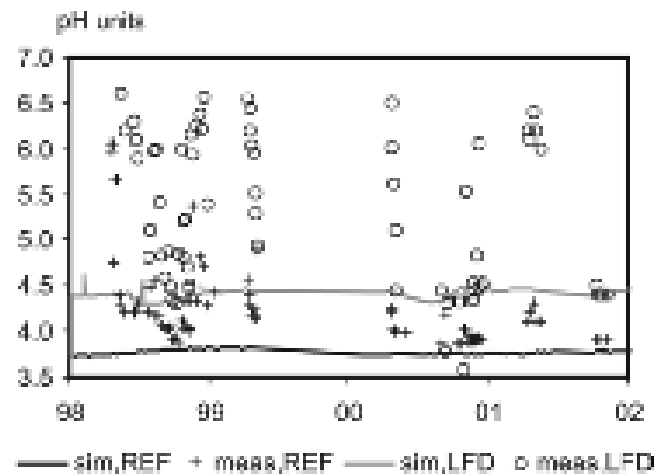

Fig. 9. Comparison of BMP effect for measured (meas) and simulated (sim) drainage water $\mathrm{pH}$ for control drainage (CD, a) and lime filter drainage (LFD, b) with ordinary subsurface drainage (REF) in Ilmajoki in the years 1998-2001.

a)

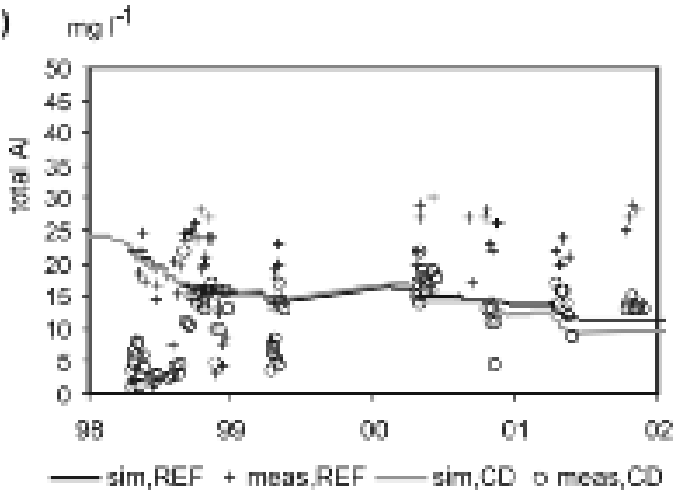

b)

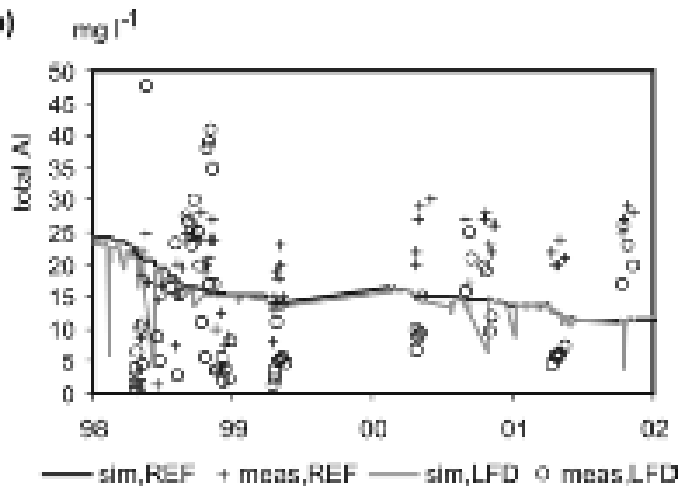

Fig. 10. Comparison of BMP effect for measured (meas) and simulated (sim) drainage water total aluminium concentration for control drainage (CD, a) and lime filter drainage (LFD, b) with ordinary subsurface drainage (REF) in Ilmajoki in the years 1998-2001. 
Vol. 14 (2005):98-111.

\section{Conclusions}

The differences in drainage water quality between Mustasaari and Ilmajoki reflect the different soil properties and drainage histories of these two sites. This difference is also reflected by the BMP effectiveness. It appears that in Ilmajoki the LFD is still active five years after installation. In general, LFD improves drainage water $\mathrm{pH}$ and reduces acidity, whereas $\mathrm{CD}$ decreases chemical leaching more efficiently. In Mustasaari, however, the effect is clearly smaller and since both increase and decrease was detected during the whole observation period it is not certain if the modified drainage methods had a positive effect at all. The concentrations of acidity and different elements in the drainage waters of Mustasaari were so high that LFD could obviously not effectively influence them. Due to the management problems in Mustasaari mentioned above, no certain conclusions can be drawn for CD. This shows, that the tested BMP's work properly, and can thus be recommended, for intensively artificially drained AS soils like in Ilmajoki where most of the acidity has already been transported to watercourses. LFD can, however, not be recommended for as yet poorly leached and thus particularly problematic AS soils like in Mustasaari. This is, of course, a drawback of the tested BMP, as it is not effective for the soils which would need it most.

The Ilmajoki field results can be utilised to test the HAPSU model. For groundwater depth the model gives reasonable results but the chemical part, both in regard to the baseline situation and the effect of the drainage methods, has to be improved. The chemical part of the model has to be calibrated and the descriptions of the BMP's properly tested. This will most probably require improvements both in the parameterisation and in the model code.

Acknowledgements. The co-operation of Heikki Harmanen (Seinäjoki Polytechnic/llmajoki school of agriculture), Unto Huttu and Tarja Savea-Nukala (West Finland Regional Environment Centre in Seinäjoki) as well as Raine Saari and Carola Storgård-Envall (West Finland Regional Environment Centre in Vaasa) and Kjell Weppling (Partek
Nordkalk Inc.) and Sirpa Joukainen (Tekla Inc.) in setting up the experiments as well as in data acquirement and analysis is gratefully acknowledged. The HAPSU model has been developed by and tested in co-operation with SCC Viatek Vesihydro, Timo Laitinen and Juha Vartia. The financial support of the HAPSU project by the Ministry of Agriculture and Forestry and Maa- ja Vesitekniikan tuki ry is gratefully acknowledged.

\section{References}

Alasaarela, E. 1982. Acidity problems caused by flood control works of the river Kyrönjoki. Publications of the Water Research Institute 49: 3-16.

Åström, M. 1998. Partitioning of transition metals in reduced and oxidised zones of sulphide-bearing finegrained sediments. Applied Geochemistry 13: 697617.

Åström, M. \& Åström, J. 1997. Geochemistry of stream water in a catchment in Finland affected by sulphidic fine sediments. Applied Geochemistry 12: 593-605.

Åström, M. \& Björklund, A. 1995. Impact of acid sulphate soils on stream water geochemistry in western Finland. Journal of Geochemical Exploration 55: 163-170.

Åström, M. \& Spiro, B. 2000. Impact of isostatic uplift and ditching of sulphidic sediments on the hydrochemistry of major and trace elements and sulphur isotope ratios in streams, Western Finland. Environmental Science and Technology 34: 1182-1188.

Bärlund, I., Tattari, S., Yli-Halla, M. \& Åström, M. 2004. Effect of intensified surface liming, control drainage and lime filter drainage on groundwater level and drainage water quality on acid sulphate soils at research fields in IImajoki and Mustasaari. Final report of the HAPSU project. Finnish Environment 732. 68 p. Available on the Internet: http://www.environment.fi/publications

Bronswijk, J.J.B. 1988. Modeling water balance, cracking and subsidence of clay soils. Journal of Hydrology 97: 199-212.

Bronswijk, J.J.B., Groenberger, J.E. \& Nugroho, K. 1992. Acid sulphate soil model. In: Acid sulphate soils on the humid tropics. AARD \& LAWOO, Jakarta, Wageningen. $284 \mathrm{p}$.

Edén P., Weppling K. \& Jokela S. 1999. Natural and landuse induced load of acidity, metals, humus and suspended matter in Lestijoki, a river in western Finland. Boreal Environment Research 4: 31-43.

FAO 1988. FAO/UNESCO Soil map of the world. Revised Legend. World Soil Resources Report 60. FAO, Rome. $140 \mathrm{p}$.

Hutka, R., Laitinen, T., Holmberg, M., Maunula, M. \& Schultz, T. 1996. Happamien sulfaattimaiden ionivirtausmalli HAPSU (Ionic flow model for acid sulphate soils HAPSU). Suomen ympäristö 8. 154 p.

Joukainen, S. \& Yli-Halla, M. 2003. Environmental impacts and acid loads from deep sulfidic layers of two well- 


\section{AGRICULTURAL AND FOOD SCIENCE}

Bärlund, I. et al. Effects of drainage techniques on groundwater level and runoff hydrochemistry

drained acid sulphate soils in western Finland. Agricultural Ecosystems \& Environment 95: 297-309.

Lahermo, P., Väänänen, P., Tarvainen, P. \& Salminen, R. 1996. Geochemical atlas of Finland, part 3: Environmental geochemistry - stream waters and sediments. Geological Survey of Finland. 149 p.

Öborn, I. 1991. Some effects of chemical weathering in three cultivated acid sulfate soils in Sweden. In: Wright, R.J. et al. (eds.). Plant-soil interactions at low pH. Developments in Plant and Soil Sciences vol. 45. Kluwer Academic Publisher, Dodrecht. p. 55-63.

Paasonen-Kivekäs, M. \& Karvonen, T. 1998. Typen huuhtoutuminen Lapuan koekentällä (Nitrogen leaching at the Lapua research field). Salaojituksen tutkimusyhdistys ry:n tiedote 24. p. 27-52. (in Finnish).

Palko, J. 1994. Acid sulphate soils and their agricultural and environmental problems in Finland. Acta Universitatis Ouluensis, series $C$, technica 75.58 p.

Ranta, E., Rita, H. \& Kouki J. 1991. Biometria, tilastotiedettä ekologeille. Yliopistopaino, Helsinki. 569 p.

Richards, L.A. 1931. Capillary conduction of liquids in porous media. Physics 1:318-333.

Sammut, J., White, I. \& Melville, M.D. 1996. Acidification of an estuarine tributary in eastern Australia due to drainage of acid sulfate soils. Marine and Freshwater Research 47: 669-684.

Sohlenius, G. \& Öborn, I. 2004. Geochemistry and partitioning of trace metals in acid sulphate soils in Sweden and Finland before and after sulphide oxidation. Geoderma 122: 167-175.

Soil Survey Staff 1999. Soil Taxonomy. A basic system of soil classification for making and interpreting soil sur- veys. USDA-NRCS. Agriculture Handbook 436. 2nd ed. US government Printing Office, Washington, DC. $896 \mathrm{p}$.

Stumm, W. \& Morgan, J J. 1981. Aquatic chemistry. 2nd ed. John Wiley \& Sons, Inc. New York. 767 p.

Teppo, A., Latvala, J. \& Sivil, M. 1999. Kyrönjoen yläosan vesistötöiden vaikutukset veden laatuun sekä kala-, rapu- ja nahkiaiskantoihin vuosina 1996-1997. Abstract: The water construction works of upper part of river Kyrönjoki and its effects on water quality and fish, lamprey and creyfish populations. Publications of Western Finland Regional Environment Centre 108. Vaasa. 80 p. (in Finnish).

Triipponen, J. 1997. Sirppujoen valuma-alueen happamuustutkimus. (Acidity study of the Sirppujoki catchment). Lounais-Suomen ympäristökeskus. 43 p. (in Finnish).

Vehviläinen, B. 1992. Snow cover models in operational watershed forecasting. Publications of Water and Environment Research Institute 11. $112 \mathrm{p}$.

de Vries, W., Posch, M. \& Kämäri, J. 1989. Simulation of the long-term soil response to acid deposition in various buffer ranges. Water Air and Soil Pollution 48: 349-390.

Weppling, K. 1993. Hydrochemical factors affecting the neutralization demand in acid sulphate waters. Vatten 49: 161-170.

Weppling, K. 1997. On the assessment of feasible liming strategies for acid sulphate waters in Finland. Dissertationes geographicae Universitatis Tartuensis 5. 81 p.

Wesström, I., Messing, I., Linnér, H. \& Lindström J. 2001. Control drainage - effects on drain outflow and water quality. Agricultural Water Management 47: 85-100. 


\title{
SELOSTUS
}

\section{Kehittyneiden ojitusmenetelmien mitattu ja simuloitu vaikutus pohjaveden pinnan tasoon ja salaojavalunnan laatuun happamilla sulfaattimailla}

\author{
Ilona Bärlund, Sirkka Tattari, Markku Yli-Halla ja Mats Åström \\ Suomen ympäristökeskus, Maa- ja elintarviketalouden tutkimuskeskus ja Kalmarin yliopisto
}

Itämeren Litorina-vaiheen aikana syntyi runsaasti rikkiä sisältäviä sedimenttejä, joista kehittyi happamia sulfaattimaita. Happamat sulfaattimaat sijaitsevat pääasiassa Pohjanlahden rannikkoalueilla. Näiden maiden kuivatuksen yhteydessä maa happamoituu, kun alunperin sulfidimuotoinen rikki hapettuu rikkihapoksi, ja samalla metalleja vapautuu maanesteeseen ja edelleen kuivatusja valumavesiin. Vesien happamuus ja veteen liuenneet haitalliset metallit aiheuttavat herkkien lajien kasvun heikentymistä ja lisäävät niiden kuolevuutta. Useita vaihtoehtoisia menetelmiä, kuten kalkkisuodinojitusta ja säätösalaojitusta, on esitetty keinoiksi vähentää happamuutta. Kalkituksella neutraloidaan happamuus, kun taas säätösalaojituksen tavoitteena on, että sulfidikerrokset pysyvät pohjaveden pinnan alapuolella, mikä ehkäisee sulfidien hapettumista ja happamuuden muodostumista.

Tässä artikkelissa esitellään HAPSU-projektin tuloksia kahdelta koekentältä Pohjanlahden rannikkoalueella: Ilmajoelta vuosilta 1998-2002 ja Mustasaaresta vuosilta 1999-2001. Tutkimuksessa selvitettiin kalkkisuodinojituksen ja säätösalaojituksen tehokkuutta valumavesien laadun parantajana. Valumavesistä tutkittiin veden $\mathrm{pH}$, happamuus sekä sulfaatin, raudan, mangaanin ja alumiinin konsentraatiot. Lisäksi tarkasteltiin kahden erilaisen alueen vaikutusta valumavesien laatuun ja arvioitiin HAPSU-mallin käytettävyyttä.

Tutkimustulokset kertovat, miten koekentät poikkeavat toisistaan maaperän fysikaalisilta ja kemiallisilta ominaisuuksiltaan. Ilmajoella sulfidikerrokset alkavat noin kahden metrin syvyydestä, mutta Mustasaaren kentällä ne ovat lähempänä pintaa. Ominaisuudet kuvaavat alueiden historiaa. Tulosten mukaan maaperän ominaisuudet vaikuttavat merkittävästi myös menetelmien tehoon. Vaikka molempien alueiden $\mathrm{pH}: \mathrm{n}$ minimi maaprofilissa on samaa suuruusluokkaa (n. 4 pH-astetta), sijaitsee minimikohta Mustasaaressa n. metrin syvyydessä ja Ilmajoella selvästi salaojasyvyyden alapuolella. Mustasaaren kaltaisilla mailla sulfidikerrokset jäävät kesäisin pohjaveden pinnan yläpuolelle ja säätösalaojituksesta huolimatta tuottavat runsaasti happamuutta valumavesiin. Myös valumavesien metallipitoisuuksissa havaittiin selviä eroja. Ilmajoen koekentällä voitiin osoittaa, että kalkkisuodinojituksen avulla valumaveden $\mathrm{pH}$ voitiin pitää puolitoista $\mathrm{pH}$-astetta, yhdistetyllä kalkkisuodin- ja säätösalaojituksella jopa kaksi pH-astetta, korkeammalla verrattuna tavalliseen salaojitukseen vielä viisi vuotta ojituksen asennuksen jälkeen. Suurin muutos havaittiin suodatetun raudan ja alumiinin konsentraatioissa, jotka vähenivät $1 / 12$ - ja 1/13-osaan tutkimusjakson aikana yhdistetyllä kalkkisuodin- ja säätösalaojitusmenetelmällä. Mustasaaressa ei kalkkisuodinojien neutralointikapasiteetti riittänyt valumavesien happamuuden vähentämiseen. Kalibroidun HAPSU-mallin avulla voitiin pohjaveden korkeutta kuvata verrattain hyvin Ilmajoen koekentällä. Sen sijaan veden laadun kuvausta tulee mallissa kehittää edelleen. 